\title{
Avaliação isocinética de 18 pacientes do sexo masculino submetidos à correção cirúrgica da luxação acromioclavicular aguda com seguimento mínimo de dois anos
}

\author{
Isokinetic evaluation of eighteen male patients submitted to surgical corretion of acute \\ acromioclavicular luxation with a minimum two-year follow-up
}

Flavio Almeida Salles ${ }^{1}$, Américo Zoppi Fllho²

\section{RESUMO}

Foram estudados 18 pacientes submetidos ao tratamento cirúrgico de luxação acromioclavicular aguda do grau III da classificação de ALLMAN-TOSSY, todos do sexo masculino com idade média de 36 anos, foram avaliados sob o ponto de vista isocinético com tempo de evolução variando de 24 até 127 meses. A avaliação isocinética foi realizada através de um dinamômetro computadorizado marca CYBEX ${ }^{\circledR}$ modelo 6000 na velocidade angular de $60 \%$ segundo e demonstrou resultados significantes no movimento de abdução no plano neutro, com déficit no pico de torque do lado operado, quando comparado com o lado contra-lateral. Quando comparados os ombros com e sem subluxação, os com subluxação demonstraram défcit no trabalho total tanto na adução quanto na abdução no plano neutro.

Descritores: Articulação acromioclavicular; homens; luxação do ombro; dor do ombro; procedimentos ortopédicos; biomecânica; seguimentos.

\section{INTRODUÇÃO}

A articulação acromioclavicular tem sua estabilidade conferida pela cápsula articular e pelos ligamentos córacoclaviculares (conóide e trapezóide) e devido à sua posição anatômica, esta articulação é sede freqüente de traumatismos que se traduzem em perda de sua integridade articular.

A lesão total dos mecanismos estabilizadores entre o acrômio e a clavícula é a luxação acromioclavicular aguda (LACA) que pode provocar importantes perturbações na força muscular do ombro e no mecanismo de deslizamento subacromial(5).

A luxação acromioclavicular aguda e seu tratamento têm sido objeto de controvérsia desde os mais remotos relatos médicos

\section{SUMMARY}

Eighteen male patients, mean age 36 years, submitted to surgical treatment of ALLMAN-TOSSY grade III acute acromioclavicular luxation were studied. They were isokinetically evaluated during an evolution period ranging from 24 to 127 months. The isokinetic evaluation was carried out with a $\mathrm{CY}$ $B E X^{\circledR} 6000$ computerized dynamometer, at a $60^{\circ} \%$ angular speed, showing significant results in vertical abduction, with a deficit in peak torque in the operated on shoulder as compared to the contralateral side. When the groups with and without subluxation were compared a deficit in total work was observed in the group with subluxation both in adduction and abduction.

Key Words: Acromioclavicular articulation. Men. Shoulder luxation. Pain in the shoulder. Orthopedic procedures. Biomechanics. Follow-up.

\section{INTRODUCTION}

The stability of the acromioclavicular articulation is conferred by the articular capsule and by the coracoclavicular ligaments (conoid and trapezoid). Due to its anatomical situation, this joint is frequently subjected to trauma causing loss of its articular integrity.

Totally lesioned stabilizing mechanisms between the acromium and the clavicle characterize the acute acromioclavicular luxation (LACA) which causes important disorders in the shoulder muscular strength and in the subacromial sliding mechanism ${ }^{(5)}$.

The acute acromioclavicular luxation and its treatment aroused controversy since the most ancient medical reports, as early as Hippocrates in 460 B.C.

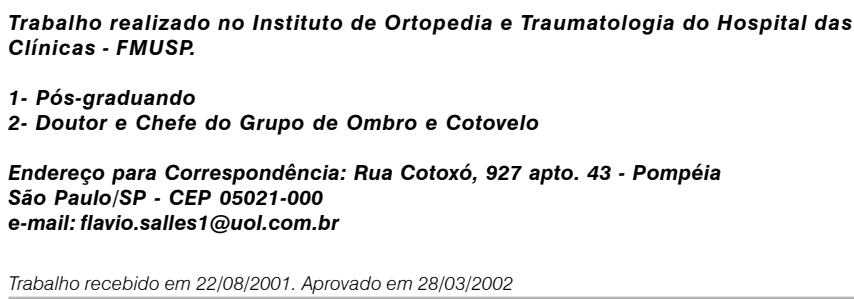


sobre o assunto, iniciando-se por Hipócrates 460 a.C.

A cirurgia do ombro vem apresentando notáveis avanços em vários campos. Os dois principais grupos de doenças do ombro - as alterações degenerativas representadas pela rotura do manguito rotador e as instabilidades abrangendo as luxações e subluxações da articulação glenumeral - apresentam protocolos de tratamento sem diferenças conceituais importantes entre os vários autores que as estudam. Com a luxação acromioclavicular e principalmente com as classificadas como grau III da classificação de Allman-Tossy ${ }^{(1,15)}$ isso não ocorre.

Optamos pela classificação de Allman-Tossy, pois algumas vezes o exame radiológico é de difícil interpretação pela má definição da articulação acromioclavicular e também por ser abrangente e mais fácil de ser interpretada, onde a luxação acromioclavicular do grau III de AllmanTossy engloba os tipos III, IV, V, VI de Rockwood ${ }^{(13)}$, que variam quanto a porcentagem do desvio e direção da extremidade distal da clavícula ${ }^{(14)}$

Embora a literatura pertinente ao assunto seja extremamente rica, não existe um consenso se a melhor opção é o tratamento conservador, aceitando-se a deformidade, ou se o tratamento cirúrgico apresenta os melhores resultados

Ainda hoje, apesar das inúmeras publicações sobre o tema, notamos que há poucas publicações relatando o resultado tardio do tratamento adotado. Resta-nos, portanto, saber o que acontece aos ombros operados em relação à função e força do membro superior.

Em nossa metodologia utilizamos um dinamômetro eletromecânico computadorizado da marca Cybéx ${ }^{\circledR}$, modelo 6000 para avaliar isocineticamente à força muscular dos ombros operados em comparação com o lado contra-lateral que é determinada através de parâmetros isocineticos específicos como pico de torque e o trabalho.

Apesar de sermos de opinião que a luxação acromioclavicular provoca uma alteração importante tanto na anatomia quanto na biomecânica da cintura escapular e deva ter sua integridade restabelecida por cirurgia, nosso estudo não tem a pretensão de encerrar as divergências entre a melhor forma de tratá-la.

O nosso objetivo foi avaliar isocinéticamente a médio e longo prazo os pacientes submetidos a tratamento cirúrgico da luxação acromioclavicular grau III de Allman-Tossy ${ }^{(1,15)}$ com acompanhamento mínimo pós-operatório de dois anos, verificando o que acontece com os ombros desses pacientes em relação a força com o passar dos anos.
Shoulder surgery has shown great advances in several fields. The two main groups of shoulder disorders - the degenerative alterations represented by rupture of the rotating sleeve and the instabilities comprehending luxations and subluxations of the glenohumeral articulation - have treatment protocols without important conceptual differences among several authors. The same is not observed as concerns the acromioclavicular luxation mainly those considered grade III by the Allman-Tossy ${ }^{(1,15)}$ classification.

We chose the AllmanTossy classification since sometimes the radiological exam is difficult to interpret due to bad definition of the acromioclavicular articulation and also because it is more comprehensive and easier to interpret. The Allman-Tossy grade III acromioclavicular luxation comprehends Rockwood's ${ }^{(13)}$ types III, IV, V, VI, which vary as concerns the deviation percentage and the direction of the clavicle distal extremity ${ }^{(14)}$.

Although the medical literature about this subject is extremely rich, no consensus exists whether the best option is the conservative treatment accepting the deformity or the surgical treatment.

Today, notwithstanding several publications about the theme, we notice that few of them report the late results of the adopted treatment. Thus, we must get acquainted with what happens to the operated on shoulders as concerns function and strength of the upper limb.

In our methodology, we used the Cybex ${ }^{\circledR} 6000$ computerized electromechanical dynamometer to isokinetically evaluate the muscular strength of the operated on limbs as compared to the contralateral side. This is determined through specific isokinetic parameters as peak torque and work.

Although in our opinion the acromioclavicular luxation causes an important alteration not only in the anatomy but also in the biomechanics of the scapular neck and must have its integrity restored through surgery, our study does not intend to resolve the divergencies about which one is the best treatment.

Our objective was to isokinetically evaluate at short and long term the patients submitted to surgical treatment of the Allman-Tossy(1,15) grade III acromioclavicular luxation with a minimum two-year post-operative follow-up, observing what happens to these patients shoulders as concerns strength. 


\section{CASUÍSTICA E MÉTODO}

No período de dezembro de 2000 a janeiro de 2001 . foram avaliados isocinéticamente com o dinamômetro marca Cybex ${ }^{\circledR}$, modelo 6000 , 18 pacientes do sexo masculino com faixa etária entre 25 e 54 anos (idade media de 36 anos), submetidos ao tratamento cirúrgico com diagnóstico prévio de luxação acromioclavicular do grau III de Allman-Tossy e acompanhamento pós-operatório que variou de 24 a 127 meses com média de 70.1 meses. As técnicas cirurgicas envolvidas neste estudo foram Vukov ${ }^{(16)}$, Phemister ${ }^{(11)}$ + reparação dos ligamentos coracoclaviculares, AmarriIho subcoracóide(8) e Weaver Dunn ${ }^{(18)}$. Dados colhidos demonstraram um padrão no protocolo de reabilitação pós-operatório dos pacientes, que retornaram aos suas atividades profissionais e de vida diária em um período que variou entre 60 e 120 dias após a cirurgia.

Como critério de inclusão, nenhum paciente poderia apresentar dor ou qualquer anormalidade no ombro contra-lateral, sendo esses ombros considerados o grupo controle.

Os movimentos realizados foram a abdução e a adução do ombro envolvido e depois do ombro contra-lateral nos planos neutro(vertical) e horizontal com quatro repetições e velocidade angular de $60 \%$ segundo

Foram utilizados os seguintes parâmetros de avaliação isocinética como: pico de torque ou torque máximo que representa o maior valor encontrado ao longo de todo arco de movimento, medido em Newton $x$ metro $(\mathrm{N} \times \mathrm{m})$ e trabalho total definido como o produto entre a força aplicada e a distância total através da qual essa força é aplicada que representa a força de contração muscular feita durante todo o arco de movimento, medido em Joules (J).

Na análise estatística foi utilizado o teste de Mann Whitney para comparar o grupo de pacientes que evoluíram com subluxação residual, di-

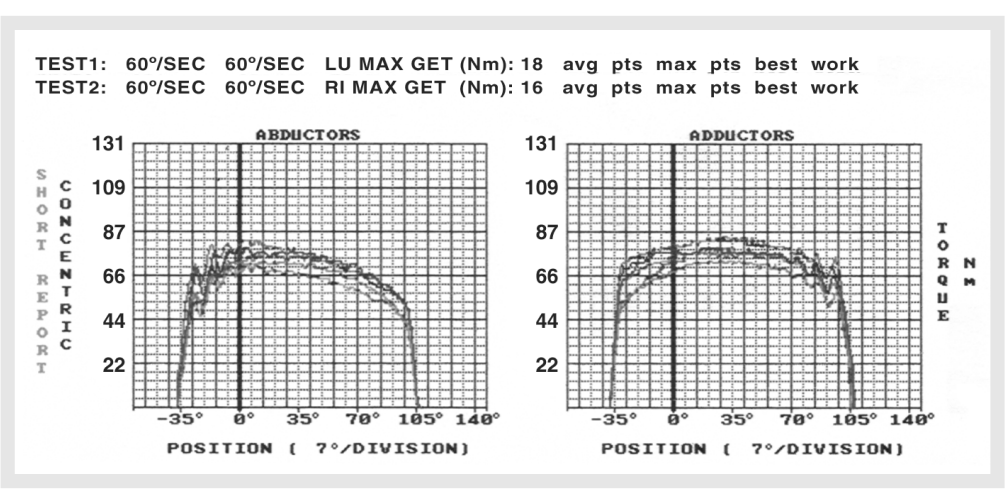

Figura 3 - Representação gráfica da avaliação isocinética dos movimentos de abdução e adução do ombro.

Figure 3 - Graphic representation of the isokinetic evaluation of the shoulder abduction and adduction movements.

\section{CASUISTIC AND METHODS}

From December 2000 to January 2001, 18 male 25-54 year-old (mean 36 years) patients with previous diagnosis of Allman-Tossi grade III acromioclavicular luxation and submitted to surgical treatment were isokinetically evaluated using the Cyber ${ }^{\circledR} 6000$ dynamometer. They were post-operatively followed-up from 24-127 (mean 70.1) months. The surgical techniques involved in this study were Vukov ${ }^{(16)}$, Phemister ${ }^{(11)}$ plus coracoclavicular ligaments reparation, subcoracoid thread ${ }^{(8)}$ and Weaver Dunn ${ }^{(18)}$. The collected data showed a pattern in the postoperative rehabilitation protocol of the patients, who resumed their professional and daily life activities in a period ranging from 60 to 120 days after surgery.

As inclusion criterion none of the patients should present pain or any abnormality in the contralateral shoulder and these shoulders would be considered the control group.

The movements were abduction and adduction of the affected shoulder and then of the contralateral shoulder in the vertical and horizontal plans with four repetitions and angular speed of $60^{\circ} /$ second.

The following isokinetic parameters were used: peak or maximum torque representing the highest value found in the full arch movement, measured in Newton $x$ meter $(N \times m)$ and total work defined as the product of the applied force and the total distance through which that force is applied, representing the muscular contraction force during the full arch movement, measured in Joules (J).

In the statistical analysis, the Mann Whitney test was used to compare the group of patients which evolved with radiologically diagnosed residual subluxation in the acromioclavicular articulation and the group without subluxation.

\section{RESULTS}

The results were the comparison of the affected shoulder with 
agnosticada radiologicamente, da articulação acromiclavicular e o grupo sem subluxação.

\section{RESULTADOS}

Os resultados foram obtidos através da avaliação isociinética dos ombros envolvidos em comparação com o ombro contra-lateral em cada movimento (abdução e adução), posicionamento (neutro e horizontal) e parâmetros isocinéticos (Pico de torque e Trabalho) estudados e também realizamos um estudo estatístico onde comparamos os resultados do estudo isocinético entre os grupos de indivíduos com e sem subluxação residual.

Dos 18 ombros estudados a avaliação isocinética demostrou:

- Déficit no pico de torque da musculatura abdutora do ombro operado no plano neutro quando comparada com a do ombro contra-lateral (tabela 1).

- A presença de subluxação residual da articulação acromiclavicular levando a uma diminuição do trabaIho total da musculatura abdutora e adutora no plano neutro (tabela 2).

\section{DISCUSSÃO}

Não foi nosso objetivo avaliar ou discutir qual a técnica mais apropriada no tratamento cirúrgico daluxação acromioclavicular, mas verificar como os pacientes evoluíram após período mínimo de dois anos com relação a força dos ombros operados.

Sabemos que a perda da integridade anatômica normal da articulação acromioclavicular pode afetar em maior ou menor grau o mecanismo suspensor da escápula ${ }^{(5)}$ ocasionando alterações na biomecânica do ombro como: fadiga muscular, síndrome do impacto e acelerar alterações degenerativas articulares ${ }^{(8)}$.

Com base nos fatos acima, objetivamos através da avaliação isocinética à correlaciona-los com possíveis alterações na força do ombro.

Utilizamos um dinamômetro eletromecânico computadorizado da marca Cybéx ${ }^{\circledR}$, modelo 6000 para avaliar isocineticamente os pacientes quanto à força dos ombros operados ${ }^{(3,12)} \mathrm{em}$ comparação com o ombro contra-lateral que foi nosso grupo contro-

\begin{tabular}{l|c|c}
\hline \multicolumn{2}{|c}{ PICO DE TORQUE (N. m) } \\
\hline & OPERAD0 & NÃO OPERADO \\
\hline $\mathrm{M}$ & 71 & 74,7 \\
\hline $\mathrm{Dp}$ & 18,8 & 20,6 \\
\hline Epm & 4,4 & 4,9 \\
\hline Mín & 39 & 35 \\
\hline Máx & 114 & 106 \\
\hline $\mathrm{N}$ & 18 & 18 \\
\hline
\end{tabular}

Tabela 1 - Resultados da avaliação isocinética do pico de torque (N.m) dos abdutores no plano neutro. M: média, Dp: desvio padrão, Epm: erro padrão da média, Mín: mínimo, Máx: máximo, $\mathbf{N}$ : número da amostra. Teste "t" pareado $p=0,049^{*}\left({ }^{*}\right.$ significante).

Table 1 - Results of the peak torque (N.m) isokinetic evaluation, abductors in the vertical plan.

M: mean, SD: standard deviation, Mse: mean standard error, Min: minimun, Max: maximum, $\mathbf{N}$ : sample number. Paired test " $t$ " $p=0,049 *$ (* significant).

\begin{tabular}{l|c|c}
\hline \multicolumn{2}{|c}{ TRABALHO (J) } \\
\hline & S / SUBLUX. & C / SUBLUX. \\
\hline M & 161 & 119,2 \\
\hline Dp & 42,4 & 38,2 \\
\hline Epm & 14,1 & 12,7 \\
\hline Mín & 98 & 61 \\
\hline Máx & 217 & 186 \\
\hline N & 9 & 9 \\
\hline
\end{tabular}

Tabela 2 - Relação entre os pacientes sem e com subluxação acromioclavicular no ombro operado, durante a avaliação do trabalho total na abdução no plano neutro. M: média, Dp: desvio padrão, Epm: erro padrão da média, Mín: mínimo, Máx: máximo, $\mathrm{N}$ : número da amostra.

Mann Whitney $p=0,0314^{*}$ (* significante).

Table 2 - Relationship between patients without and with acromioclavicular sub-luxation in the operated

on shoulder during total work evaluation in the vertical plan abduction.

M: mean, SD: standard deviation, Mse: mean standard error, Min: minimum,

Max: maximum, $\mathbf{N}$ : sample number. Mann Whitney $p=0,0314^{*}$ (*significant) the contralateral shoulder as concerns movement (abduction and adduction), positioning (vertical and horizontal), and isokinetic parameters (peak torque and work); a statistical study was also carried out comparing the results of the isokinetic study among the with and without residual subluxation groups of patients.

The 18 shoulders isokinetic evaluation has shown:

- Deficit in the peak torque of the operated on shoulder abductor muscles in the vertical plan, as compared to the contralateral shoulder (table 1).

- Presence of residual subluxation in the acromioclavicular articulation leading to diminution of the abductor and adductor muscles total work in the vertical plan (table 2).

\section{DISCUSSION}

The aim of our study was to determine the patients ' evolution after a minimum two-year period as concerns strength of the operated on shoulders. It was not our intention to evaluate and discuss the most appropriate surgical technique to treat the acromioclavicular luxation.

We know that loss of the acromioclavicular joint normal anatomical integrity can affect the scapular suspensory mechanism ${ }^{(5)}$ causing alterations in the shoulder biomechanics as: muscular fatigue, impact syndrome and acceleration of the degenerative articular alterations ${ }^{(8)}$.

Considering the facts above, we aimed through the isokinetic evaluation to correlate these facts with possible alterations in the shoulder strength.

We used the computerized electromechanical dynamometer Cybex ${ }^{\circledR} 6000$ to isokinetically evaluate the patients as concerns strength of the operated on shoulders ${ }^{(3,12)}$ as compared with the contralateral shoulders that were our control group, thus eliminating the differences in strength between individuals with large differences of age.

Considering that the early methods to evaluate the shoul- 
le evitando assim as diferença de força entre os indivíduos com grande disparidade de idade.

Tendo em vista que os antigos métodos de avaliação dos parâmetros funcionais do ombro como tensiômetros a cabo, dinamômetros manuais apresentavam limitações quanto à técnica de mensuração, reprodutibilidade e principalmente à falta de objetividade, vemos que a avaliação isocinética é um fator objetivo na avaliação de tratamentos ortopédicos realizados e bastante difundido em nosso meio.

Enquanto os exames clínicos e radiológicos fornecem dados que podem diferir conforme o examinador, a avaliação isocinética permite a demonstração de dados objetivos e a documentação da analise dinâmica dos movimentos do ombro, independente do exame clínico a que o paciente é submetido, da interpretação de exames de imagem e outros tantos fatores ${ }^{(2)}$.

Para escolha deste método de avaliação, fundamentamo-nos nos estudos de Moffroid(7) e Patton ${ }^{(10)}$ que estabeleceram as primeiras normas para avaliação isocinética e salientaram a importância deste exame como método fidedigno e reprodutível de avaliação muscular ${ }^{(6)}$.

Os parâmetros utilizados para avaliar a força do ombro foram o pico de torque e o trabalho total, aqui representados por resultados numéricos e gráficos após o paciente realizar o movimento contra uma resistência acomodativa ${ }^{(4)}$.

O pico de torque é sem dúvida o parâmetro mais difundido na literatura, considerado de fácil determinação e definido como dado mais fidedigno de mensuração( ${ }^{(9)}$, representando o valor máximo atingido durante a contração muscular em dado momento do movimento. Este parâmetro revelou-se estatisticamente significante no movimento de abdução no plano neutro $(p=0,049)$ (tabela 1). Acreditamos que vários fatores clínicos como: dor, atrofia da musculatura e radiográficos como: subluxação e alterações degenerativas possam estar atuando isolados ou associadamente na gênese desta alteração.

Outro dado colhido nesta avaliação foi o trabalho total, parâmetro que representa a força de contração muscular durante todo o tempo de realização do movimento tornando a interpretação e a avaliação dos resultados sobre a capacidade funcional total do indivíduo mais representativas $^{(17)}$. Nossa casuística não demonstrou diferença estatisticamente significante para o trabalho total em todos os movimentos estudados. Acreditamos ser este um resultado importante, salientando a recuperação da força muscular destes pacientes após o período de evolução que teve como média 70,1 meses.

Ainda entre os parâmetros avaliados foi incluída a relação entre as musculaturas agonísta, representada pela musculatura ab-
TRABALHO (J)

\begin{tabular}{c} 
C / SUBLUX. \\
\hline 135,2 \\
\hline 38,2 \\
\hline 12,7 \\
\hline 76 \\
\hline 194 \\
\hline 9
\end{tabular}

Tabela 3 - Relação entre os pacientes sem e com subluxação acromioclavicular no ombro operado, durante a avaliação do trabalho total na adução no meutro. M: média, Dp: desvio padrão, Epm. răo da média, Mín: mínimo, Máx: máximo $p=0,0313^{*}$ (*significante).

Table 3 - Relationship between patients without and ( M: mean, SD: standard standard error, Min:
, N: sample number. $313^{*}$ (* significant). der functional parameters as tensiometers and manual dynamometers presented limitations as measuring techniques, reproductibility, and mainly lack of objectivity, we found that the isokinetic evaluation is an objective widely known factor to evaluate orthopedic treatments among us.

As the clinical and radiological exams provide data which can differ according to the examiner, the isokinetic evaluation allows the demonstration of objective data and the documentation of the shoulder movements dynamic analysis, independently of the clinical exam, of the interpretation of the image exams, and many other factors ${ }^{(2)}$.

To choose this method, we based ourselves in the Moffroid(7) and Patton ${ }^{(10)}$ studies which established the first norms for the isokinetic evaluation and underlined the importance of this exam as a reliable and reproductible method for muscular evaluation ${ }^{(6)}$.

The parameters used to evaluate the shoulder strength were peak torque and total work, represented by numerical and graphic results after the patients effect the movement against an accomodative resistance ${ }^{(4)}$.

The peak torque is undoubtedly the most mentioned parameter in the literature, easy to determine and defined as the most reliable measurement ${ }^{(9)}$, representing the maximum value attained during muscular contraction in a certain moment of the movement. This parameter was statistically significant in the abduction movement in the vertical plan ( $p=0.049)$ (table 1). We believe that several clinical factors as pain, atrophy of the muscles and radiographic factors as subluxation and degenerative alterations can be acting in isolation or in association in the genesis of this alteration.

Another determination was total work, a parameter which represents the muscular contraction strength during all the time the movement is being carried out, making more representative the interpretation and evaluation of the results concerning the total functional capacity of the subjects ${ }^{(17)}$. Our casuistic did not show a statistically significant difference for total work in all the movements studied. We believe this is an important result, emphasizing recuperation of these patients ' muscular strength after the evolution period that lasted on average 70.1 months.

Also among the evaluated parameters, the relationship between the agonist muscles represented by the abductor muscles and the antagonist by the adductor was included aiming to study the equilibrium between these muscular groups usually demonstrating adductor muscles stronger than 
dutora, e antagonista pela adutora com o objetivo de estudar o equilíbrio entre esses grupos musculares que normalmente demonstra uma musculatura adutora mais forte do que a abdutora na articulação do ombro. Esse padrão manteve-se durante nosso estudo não havendo resultados estatisticamente significantes nos parâmetros estudados, fato este que demonstra também uma reabilitação do equilíbrio muscular normal.

Realizamos também um estudo comparativo entre os indivíduos que apresentavam a clavícula sem subluxação e com subluxação (grau II de Allman - Tossy) residual. Os resultados demonstraram-se estatisticamente significantes nos movimentos de abdução $\left(p=0,0314^{*}\right)$ (tabela 2) e adução $\left(p=0,0313^{\star}\right)$ (tabela 3) no plano neutro, fato explicado por fatores como: perda da congruência da articulação acromioclavicular associada à alteração nas inserções dos músculos deltóide e trapézio, que acreditamos interferir diretamente na biomecânica do ombro.

Encontramos na avaliação isocinética alterações estatisticamente significativas, porém acreditamos que esses resultados não tem correlação com a função do ombro nas atividades de vida diária (AVD) ou quadros dolorosos, e sim representa a diminuição da força muscular em movimentos específicos da articulação uma vez que a totalidade dos pacientes estudados não se queixavam de dor ou limitação funcional nas AVD.

Talvez para diminuir dúvidas sobre qual seria realmente a melhor opção de tratamento da LACA, um estudo com avaliação isocinética deva ser feito nos pacientes submetidos a tratamento conservador seguindo essa mesma metodologia aqui empregada.

\section{REFERÊNCIAS BIBLIOGRÁFICAS}

1. Allman, J.R.: Fratures and ligamentous injuries of clavicle and its articulation. J. Bone Joint Surg. [Am]., v. 49, p. 774-84, 1967.

2. Beasley, W.C.: Influence of method on estimates of normal knee extensor force among normal and postpolio children. Phys. Ther. Rev., v36, p 21-41, 1956.

3. Castropil, W. Avaliação clínica e isocinética de 30 atletas submetidos ao tratamento cirúrgico da instabilidade anterior do ombro pela reparação da lesão de Bankart associada à capsuloplasia anterior por via aberta. São Paulo, 2000. 126 p. Tese (Mestrado) - Faculdade de Medicina, Universidade de São Paulo.

4. Elliot, J.: Assessing muscle strength isokinetically. JAMA., v. 24, p.2410-1, 1978

5. Fukuda, K., Craig, E.V., An, K., Cofield, R.H., Chao, E.Y.S.: Biomechanical study of ligament system of the acromioclavicular joint. J. Bone Joint Surg. [Am]., v.68, p.434-39, 1986.

6. Kuhlman, J. R.; Iannotti, J. P.; Kelly, M. J.; Riegler, F. X.; Gevaert, M. L.; Ergin, T. M. Isokinetic and isometric measurement of strenght of external rotation and abduction of the shoulder. J. Bone Joint Surg. [Am]., v. 74, p. 1320-33, 1992.

7. Moffroid, M., Whipple, R., Hofkosh, M.S., Lowman, E., Thistle, H.A.: Study of isokinetic exercise. Phys. Ther., v. 49, p. 735-46, 1969.

8. Neer, C.S.: Shoulder reconstruction., Philadelphia, Saunders, 1990. Cap. 4, p.341-55: Dislocations.

9. Ostering, L.R.: Optional isokinetic loads and velocities producing muscular power in human subjects. Arch. Phis. Med. Rehabil., v. 56, p. $152-5,1975$. the abductor in the shoulder articulation. This pattern was maintained during our study and we did not find statistically significant results in the studied parameters; this shows also rehabilitation of the normal muscular equilibrium.

We have also carried out a comparative study between subjects presenting clavicles without residual subluxation and with residual subluxation (Allam-Tossy). The results were statistically significant for the abduction ( $\left.p=0.0314^{*}\right)$ (table 2) and adduction ( $p=0.0313^{*}$ ) movements (table 3 ) in the vertical plan; this can be explained by factors as loss of the acromioclavicular articulation congruence associated to alterations in the deltoid and trapezoid muscles insertions that directly interfere in the shoulder biomechanics.

We found statistically significant alterations in the isokinetic evaluation, however we believe that these results are not correlated with the shoulder function in daily life activities (AVD) or with painful conditions, but represents less muscular strength in specific movements of the articulation, since all studied patients did not complain about pain of functional limitation in the AVDs.

In order to reduce the doubts concerning the best option to treat $L A C A$, a study with isokinetic evaluation should be made with patients submitted to the conservative treatment, following the methodology used in this study.

10. Patton, R.W., Hinson, M.M., Arnold, B.R., Lessard, B.: Fatigue curves of isokinetic contractions. Arch. Phys. Med. Rehabil., v. 59, p. 507-9, 1978.

11. Phemister, D.B.: The treatment of dislocation of the acromioclavicular joint by open reduction and theaded-wire fixation. J. Bone Joint Surg., v 24, p 166-68, 1942.

12. Press, J.; Zuckerman, J. D.; Gallagher, M.; Cuono, F. Treatment of grade III acromivlavicular separations. Operative versus nonoperative management. Bull Hosp Jt Dis., v.56, p. 77-86, 1997.

13. Rockwood, C. A., Jr. Subluxations and dislocation about the shoulder. In: Rockwood, C. A., Jr; Green, D. P., Fractures. 2., ed Philadelphia, J. B. Lippincott, 1984. p. 860-910.

14. Taft, T. N.; Wilson, F. C.; Oglesby. W.; Hill, C. Dislocation of the acromioclavicular joint: and end results study. J. Bone Joint Surg. [Am]., v. 69, p. 1045-51, 1987.

15. Tossy, J.D., Mead, N.C., Sigmond, H.M.: Acromioclavicular separation: useful and practical classification for treatment. Clin. Orthop., v. 28 , p. 111-19,

16. Vukov, W.: Clinical experience with a new way of clavicle fixation in acromioclavicular injuries. In: Post, M., Morrey, B. F., Hawkins, R. J., ed. Surgery of the shoulder. St. Louis, Mosby, 1990. p.98-100.

17. Warner, J. J. P.; Micheli, L. J.; Arslanian, L.E.; Kennedy, J.; Kennedy, R. Patterns of flexibility, laxity and strength in normal shoulders and shoulders with instability and impingement. Am. J. Sports Med., v. 18, p. 366-75, 1990.

18. Weaver, J.K., Dunn, H.K.: Treatment of acromioclavicular injuries, especially complete acromioclavicular separation. J. Bone Joint Surg. [Am]., v.54, p.1187-94, 1972. 